\title{
IS POLISH PATIENTS' FEAR TOO BIG TO BE TRUE? EMOTIONS EXPRESSED BY PATIENTS ON MEDICAL PORTALS
}

\begin{abstract}
The article examines the question of emotions experienced by patients, users of medical portals, who "found themselves" in the complex structure of the healthcare system in Poland, emotions arising from interactions with medical professionals, and in the process of experiencing the course of disease. Statements published by users of medical portals/internet forums were analyzed. The research sample consisted of 15 medical portals with high level of activity of registered users. The analysis was based on statements describing the situation (or its context, or actions of participants involved in the interactions) determining the experienced emotions.

Keywords: emotions of Polish patients, users of medical portals, health, action-situation, Polish healthcare system.
\end{abstract}

\section{Introduction}

Health - in axiological terms belongs to the most desirable human values. It is believed that the strength of the desire for this value is significant, and so are the means of validating the emotional attitudes of individuals towards health (Kowalski, Gaweł 2006: 54). The Poles (55\%) prioritize health (maintaining good health) over success, fame, career or prosperity and wealth (Boguszewski 2019). It is therefore hardly surprising that the threat to this value evokes great and often extreme emotions (cf. Konecki, Pawłowska 2013: 7-9). It is thus worth examining which ones dominate the descriptions of experiences (situations/ actions) of users of Polish medical portals, as it is most often in the virtual world

* Associate Professor, Katedra Socjologii Polityki i Moralności, Instytut Socjologii, Wydział Ekonomiczno-Socjologiczny, Uniwersytet Łódzki, ul. Rewolucji 1905 r. 41/43, 90-214 Łódź, e-mail: alicja.formejster@uni.lodz.pl 
that patients share opinions, experiences and useful information about functioning in the healthcare system in Poland.

The latter are all the more desirable because the restructuring changes implemented since the 80 s make the health care system appear complicated and unfriendly to the patient, in which procedures and standardization are more important than the well-being of an individual. And yet the subject forced to act in this complex structure is the patient, who must take care of his own well-being or that of his loved ones.

The need to act "independently", and often alone, evokes different emotions in patients, which equally often motivate and demotivate them; or inspire them to seek help through modern technological solutions. Thus, the profile of a modern patient is changing, as they increasingly want to consciously and actively participate in the treatment process and want to be an informed partner in the conversation about implemented medical procedures and participate in their choice. They gain knowledge about health from the Internet, consult on discussion forums, and expect high quality of services (Dolińska-Zygmunt 2001:274).

This activity is not indifferent to the sphere of the patient's emotions. The more so that the implemented legislative, structural and organizational solutions, which "theoretically" aim at providing safe health care at the highest possible level, often bring the opposite effect. They result in increased bureaucratization and unmet needs and expectations of recipients of medical services, often resulting in submission of a request/complaint to the entity established for this purpose, which can be interpreted as a manifestation of extremely negative emotions regarding unsatisfied demands, feeling of powerlessness or violation of patients' rights (see Łaska-Formejster 2015).

Confirmation of the lack of satisfaction of patients' needs (e.g. to establish trust and a sense of certainty about the proposed therapies) is the fact that almost $60 \%$ of Poles, after visiting a specialist, check the information obtained, and $17 \%$ abandon the doctor's orders, choosing advice from the Internet (CBOS 2016), which may indicate a lack of trust in the doctor, an improper course of the doctorpatient relationship or a lack of understanding of the essence of the treatment process proposed by the doctor (at the level of transmission and understanding of information).

Problems addressed in this study concerns the emotions experienced by patients using institutional medical assistance, who (often in acts of desperation) describe them on medical portals and forums. The discussion of the chosen problem area is based on the results of content analysis of the statements of users of 15 medical portals and a selective review, a literature query. The thesis of the article is: users of Internet portals more often publish descriptions of situations (their context and course of interaction) determining their experience of negative emotions (often extremely negative), using emotional, evaluative rhetoric (considering biographical experiences). 
The area of concern guided the conceptual nature of the analysis. The presentation therefore includes an analysis of patients' emotions in an interactional paradigm. An important assumption of this position is the belief that social factors are involved in the creation of emotions. This is done through codification, expression, and management (Hochschild 2009: 226). One can assume, according to Blumer, that the influence of these independent external factors that affect the individual is always mediated through processes of interpretation and definition (Blumer 1969: 135). The perspective of experiences in medical relationships is not one-dimensional, each patient-physician (medical staff) encounter can be (and most often is) defined differently and then the emotions initiated are conditioned from a particular causal perspective (Ekman, Davidson 1999). It is precisely this perspective that inspired the creation of the analytic categories (the two fundamental ones are described later in this article).

What is interesting is which characteristics of the situations described by the patients (= actions of others) evoke certain emotions in them, which emotions result from active participation in these situations? In this context, emotions should be regarded as a social product "that depends each time on the participants' definition of the situation and the interpretations and reinterpretations they impose on their own actions and those of their interaction partners"1 (cf. Kacperczyk 2013: 72).

\section{Patients' online activity}

Nowadays, most people (especially in computerized societies) cannot imagine functioning without the Internet. It is estimated (based on DIGITAL 2020) that in $2020,4.5$ billion people worldwide had access to the network (that's about $53 \%$ of the 7.5 billion population) and 3.8 billion were using social networking applications. In Poland, more than 27.4 million people currently use the Internet, so more than $84.2 \%$ of households have access to the web (Gemius 2018).

The spread of the Internet, therefore, opens up new communication possibilities, delineates new research areas, and makes it possible to reach new groups of respondents (Gregor, Stawiszyński 2005: 333-334). Research success increases the sense of confidentiality (Batorski et al. 2006), and this is a factor that significantly affects the quantity and quality of responses (Batorski et a1.2006: 102). According to the analyses, in research with the use of computers, respondents are more likely to share private and even intimate information with others, and this is because: they have a sense of anonymity (including visual anonymity); they focus on their own attitudes and emotions; the very act of writing promotes confiding (cf. Staniszewska 2013: 52).

${ }^{1}$ All quotations in the text are own translations. 
The search for information, support and help, the opportunity to share opinions, experiences, often intimate, is nowadays transferred to the level of online relationships created within Internet groups and forums. It is therefore justified, both from the methodological and issue-related point of view, to analyze the statements of users of medical forums and portals. The more so because modern patients are becoming more active in this very space. Another important reason is also the fact that $47.7 \%$ of Poles look for information about diseases, treatments and doctors on the Internet (Business Insider Polska 2019).

The research sample consisted of 15 medical portals (on the following topics: internal medicine, gynecology and obstetrics, ophthalmology, surgery, oncology, dentistry, eating disorders, dermatology, cardiovascular diseases), which had a high number of active users (on selected ones there were even more than 10 thousand registered users). The research was carried out in the period: June-September 2019, and 256 statements were qualified for the final analysis. A part of the results of the analysis, consistent with the adopted paradigm, in which situations (their causal context) determine the emotions experienced, is presented below.

\section{Emotions of patients - users of medical Internet portals and forums}

At the beginning, I would like to point out one of the difficulties of the study which was the process of codifying the statements in which the emotional context appeared - and in which the emotions were not always precisely indicated (the secondary ones, resulting from the occurrence of primary emotions in specific social situations (Kemper 1987; Kemper 2005)). The expression of emotions, and the difficulties associated with it, are conditioned by many factors, but an important feature of the sources was also that the purpose of the forums and portals was not strictly to express said emotions. However, the description of the situation (the action taken), the sequential nature and the "relative" thematic consistency of the statements made by users of Internet portals and forums made it possible to classify them and formulate conclusions. Hence, the presentation of the results of the analysis of particular situational contexts (features of the situation that were classified as analytical categories) is not always exemplified by quotations, statements of the respondents.

Issues related to such important human values as life and health already evoke extreme emotions. When the question of threatening these values arises, experiencing pain and suffering, the feeling of helplessness as well as "human" and systemic loneliness - these emotions often decide about the actions and procedures undertaken by patients. Emotions influence behavior and are a response to environmental conditions. It is emotions that give patients a particular readiness to act. It is also important to point out the process when actions and experiences elicit specific emotions. Changing social actions give meaning to and influence the 
ongoing feeling of specific emotions (Lewis, Haviland-Jones 2005: 72-86). Emotions in this context are contingent on a particular causal perspective (cf. Ekman, Davidson 1999).

In the analyzed materials both dimensions of experienced emotions were present (although in different proportions) - and in the one (dimension) inducing actions, when, for example, fear, anxiety, concerns were the stimuli to seek medical help and initiate relationships with health care professionals. And in the dimension resulting from the implemented procedures; when, as a result of the medical consultation, learning the diagnosis, the patient felt, for example, joy, confidence, embarrassment, irritation, anger, fear or despondency, and then it was the actions that gave meaning and evoked specific emotions.

The second type of emotions, evoked by a particular action, situation, course of interaction (or failure to meet expectations), significantly dominated in the source materials. This may result from the very specific nature of the forums and portals, where in the vast majority, people who were registered had already experienced the first emotions related to the observation of alarming symptoms of illness in themselves or a family member, initiated the procedure for medical assistance and made a preliminary or detailed diagnosis. However, there were also entries (there were a number of them), in which new users asked other users about the "diagnosis" of the symptoms they observed in themselves - which worried them (they treated the other users as "specialists" experienced in "living with" a given disease). The experience of the illness itself played an important role in this context, which is understandable, since

[t]he type and strength of emotions associated with an illness is largely dependent on how the illness is understood and what meaning has been attached to it [...] the most common reactions to illness are negative emotions such as fear, anxiety, depression, grief, helplessness, indifference, guilt and anger (cf. Bąk-Sosnowska 2006: 175).

The following section presents the results of the analysis in which emotions are the result of action, participation in certain situations, interactions. The results are classified in two main categorical dimensions: institutional (considering rules, regulations, legal norms and interactions resulting from the need to respect them) and strictly interactional.

\subsection{The fear of the patient is, indeed, too big to be true}

The results of the analysis clearly indicate that the emotions experienced by the users of the analyzed forums in the vast majority are negative. Their source is the course of the described situations, which pertain both to experiences within the healthcare system and to interactions with medical personnel. The first contact of a person in need of medical assistance with medical institutions and its employees occurs (most often) within the healthcare system itself. Both in the early days of restructuring the healthcare system and today, complex regulations 
are little understood by the average recipient of medical services. The multitude of regulations and frequent changes in the rules of providing medical services, on the one hand, and the negligible information campaign, on the other, are not beneficial to patients. Patients have a sense of disinformation and do not know what procedures apply to a particular course of action. Even when looking for information on the Internet, they complain about its lack of transparency and timeliness. Functioning within the healthcare system turns out to be a significant source of their feelings of fear, anger, helplessness - they are particularly irritated by the fact that the interactions within it are not helpful, which they show in an expressive, evaluative way. And this is the first of the situational contexts presented below.

\subsubsection{Institutional dimension: The system (and its members) as a source of negative emotions}

The analysis shows that negative emotions (fear) are already triggered by the prospect of having to be part of the healthcare system, here is an example of a statement that appeared on a portal about ophthalmology:

I must go and register at the clinic, I'm already afraid what I will find there... what will happen... It's such a mess everywhere, they keep sending me somewhere, either the referral is not from this doctor, or the deadline has passed...; I'm scared and nervous, nobody knows anything, nobody helps...

In the context of categorized statements containing description of emotions resulting from lack of knowledge about procedures and pathways implemented in specific practices (there were dozens of them, descriptions differed by examples of diseases), there appears a picture of a system which initiates negative emotions by itself. The lack of clear information conveyed in various systemic and interactional configurations exacerbates feelings of fear, frustration, anger, hostility, rage, and helplessness in patients. From the descriptions of the context of the situations it can be concluded that the respondents (although not the majority) do not know the course of procedures, do not know where to seek treatment (most often they receive general guidelines or even suggestions to find information on the Internet), do not know the scope of benefits to which the insured are entitled, do not know where to obtain, for example, auxiliary and orthopedic aids. Complicated organizational and legal regulations are also difficult to understand and cause frustration, anger, fear and helplessness.

Users also expressed fear, anger and hostility when they described situations in which they were informed about limited access to highly specialized diagnostic tests, e.g., CT or MRI scans. They complained about being denied services on an emergency basis or about long waiting times for these services.

I am afraid, it is taking so long; I am furious! Please help me. What can I do, it's so inhumane, I might not make it...; I pay my medical fees regularly and I can't do specialized examinations 
even once - it's a shame, I don't know what else I can do, did you have the same experience, where can I go for an emergency MRI?

Some even pointed out the refusal to provide a service or to register a referral and to being placed on a waitlist. In their statements there were repeated evaluative phrases indicating strong negative emotions:

It's outrageous, how a person is treated here, how can such rules be formulated!; I am furious, how can I deal with the refusal, after all, they are also people, or rather wolves's; Again, I failed to register, what a ruthless bunch of people, irritation only comes to my mind... I am angry, angry, angry and powerless!!!; I am afraid..., it's terrible, when will they finally examine me properly, after all I am dying slowly... I will not make it! Maybe you have some advice?

Other situations described by the respondents, which evoked feelings of anger, discouragement and sometimes fear (of loss of life) in them, concerned the determining of the limit of admissions to specialists, and consequently difficulties in being admitted to specialists, notably: cardiologist, neurologist, orthopedist, gastroenterologist, ophthalmologist, endocrinologist.

The data is supported by social analyses: "The limited number of doctors generates numerous barriers to accessing healthcare, including long waiting lists" (Raport 2017). This trend has continued since 2012 (Barometr WHC 2017), "and this exodus, however, has made queues the bane of commercial medical care for several months as well" (Krzywda 2017).

Also in the systemic context, but in terms of interaction with other medical personnel, users indicated feelings of helplessness, powerlessness, fear, anger and even hostility in the following situations: when, despite experiencing severe and painful symptoms, they were forced to wait (to join the waiting list - due to existing limits) for outpatient specialist care and hospital care, while none of the medical personnel showed any interest in their condition:

I am afraid... mainly that I will not make it...; I am angry and helpless this system eliminates the sick and the weak and yet it should help them, and they want to finish us off how to get help? No one helps - heartless receptionists, no one is interested in anything; I am powerless supposedly because of the system - but people put us on the lists, or at least have someone take an interest; I am outraged they are earning more and more, I am paying more and more and I get nothing - kick them all out, maybe others will come and treat people better, you can't get any help; The system is inhumane! It's not normal how do I plan for my mom's illness - to get help and get tests done. Receptionists have great advice, but they can't sign me up?

Another category of situations evoking strong negative emotions (irritation, anger, hostility) includes those where respondents encountered barriers such as refusal to issue a certificate (e.g., temporary inability to work), postponement of

2 Plautus' maxim homo homini lupus, popularised by Th. Hobbes: man in the state of nature is selfish and fights against all. In the analysed context, this Polish idiomatic expression: Czlowiek czlowiekowi wilkiem, can be translated as someone acting in an inhumane manner towards another person. 
appointments, refusal to reimburse costs of orthopedic supplies, medical aids, or transport orders. Users also wrote about refusal to make copies of medical records, refusal to provide temporary access to the original documents, to send an electronic version of records, to review records after the death of a family member, or a general refusal to review or mismanagement of medical records.

You can go mad - again I did not get permission to make a copy of the documentation - has anyone had the same experience?; you cannot ask to borrow documentation from (hidden data about the facility), what to do I am furious and powerless; - a person has the worst thoughts when they encounter such callousness, how can you treat a sick, suffering person in such a way - and have them come several times and still not help, is it such a problem to make copies of documents.

It is interesting to note that other users tried to comfort those struggling with these difficulties and motivated them to keep trying. In doing so, they expressed positive, supportive feelings:

Not everyone is like that, I come across great people - recently the receptionist - she helped me on her own and prepared the necessary documents for further treatment; Don't worry there are still good people, be of good cheer; - I can probably talk about luck because I always manage to photocopy the papers; - it's your right, claim it I always claim it and it brings good result; Don't be discouraged - they are just people.

The above presentation already attests to the range of difficulties experienced by patients in the area of functioning in the healthcare system. Experiences in various situational contexts determine and influence their emotions, which they express in an emotional, evaluative way. Thus, the thesis that the causal context of the situation influences defining the emotions it evokes is also confirmed, and depending on the experiences, specific emotional capital is built. In the contexts referred to, strong negative emotions (fear, hostility, irritation, helplessness), expressively expressed, were evoked in situations conditioned by the structure of the healthcare system in Poland and the related legal and organizational rules (although there was also a partial theme of interaction - in the context of auxiliary staff, receptionists).

\subsubsection{The interaction dimension (the action of professionals as a source of emotions)}

Due to the nature of medical forums and portals, the topics discussed therein addressed various dimensions of medical interactions and interventions undertaken by physicians in surgical specialties such as surgery, orthopedics, dentistry, gynecology and obstetrics, ophthalmology, and non-surgical specialties (e.g., internists). In both surgical interventions and other forms of medical care, there is a wide spectrum of activities in which there can be health successes, expected and desired treatment outcomes, but also failures. These include negligence and misconduct, which may be perceived by patients as offending 
their dignity, inappropriate, carried out carelessly (leading to harm or death), unethically; all of which evoke certain emotions.

The analysis of the entries made it possible to isolate the emotions that appeared in the area of the above classification (taking into account interactions with surgical and non-surgical physicians). However, it should be noted at the outset that users of portals and forums (regardless of physician's specialty), also wrote about fear related to prognosis. Fear intertwined with hope were the first emotions (depending on the stage of the disease) they mentioned. They described fear of both diagnosis and prognosis, as well as planning for further treatment (whether, for example, it would involve a financial burden they could not manage) and hope for recovery. In these contexts, patients primarily expressed trust and confidence in their doctors' skills and competence towards their doctors.

I don't know what will happen, if there is improvement, what the prognosis is, it paralyzes me - I am afraid, but I hope that the doctor will help - she is great!

A different emotional context appeared in the entries in which patients (again, regardless of the doctor's specialty) motivated their fear by the lack of having acquired information or by the lack of a proper course of interaction. Yet already Parsons emphasized that the doctor, while performing basic diagnostic and therapeutic activities, may create emotional problems for the patient, and only expressive activities may restore the disturbed balance (Jarosz 1978: 277). It turns out that doctors (as reported by users of forums and portals) do not take into consideration patients' emotional needs during visits; they rarely dedicate enough time to explain all aspects related to the diagnosis, discuss the course of treatment and the possibility of introducing various therapies. Only the sickest patients (e.g., oncological patients) received this kind of support. For the most part, they wrote about the care given by physicians and appreciated their efforts in choosing words when talking about prognosis and further treatment procedures (they put their trust in them - while resentments, frustrations, anger, and hostility were expressed in the context of functioning in a system that limits treatment options and therapies).

If I were to compare the emotions that patients wrote about in the context of relationships with representatives of different medical specialties, the more extreme emotions were expressed by the respondents in the case of interactions that included treatment procedures of a surgical nature. Fear was induced in them not only by the necessity and prospect of the procedure, but unfortunately it was again compounded by the lack of information and the sometimes unfriendly course of the patient-physician interaction. Problems and lack of understanding between the patient and the doctor have been reported for a long time, which consequently leads to conflicts and serious mistakes in the treatment process (Makara-Studzińska 2012: 48). The most common mistakes that disrupt the relationship between patients and doctors include mutual criticizing and judging, giving orders, 
advising, moralizing, inappropriate and excessive questioning from both the doctor and the patient, and medical jargon that is incomprehensible to the patient (Makara-Studzińska 2012: 48-57). In fact, in the published posts, the patients mention (among the elements of the visit affecting the emotions of fear, anger, irritation, helplessness) such features as too short time devoted to examination and conversation, disrespectful attitude of physicians, belittling of the described symptoms, disregard for feelings of the patient, lack of skills to communicate difficult and sensitive information. And yet the course of communication between the doctor and the patient is crucial for the treatment outcomes.

They also emphasized that they had a feeling of helplessness and felt anger in situations when doctors (especially surgeons) did not provide any information. The analysis shows that physicians and auxiliary medical staff do not prepare the patient (or their family) for upcoming treatments and procedures. Patients do not receive information, and if they do, it is perfunctory, laconic - causing more anxiety rather than explaining and calming the patient.

The worst thing is when they don't say anything - they ask permission - but for what? - for everything?... A person is powerless, helpless, afraid and fed up; - for me the doctors at the hospital were nice, but the nurses - if you ask them anything, they will answer you like they would to a dog, they will not help you - you are ill and here you are subjected to such humiliation.

The respondents, expressing their fear, anger and helplessness, also wrote about the haste of physicians, rude behaviour, presence of third parties during examinations (lack of respect for the right to intimacy and dignity). The fear associated with the necessity to intervene in the corporeality seems natural; however, even this fear may be minimized with appropriate support, empathy and proper course of interactions. Such situations were described especially by patients who underwent "major" surgeries - e.g., on the heart or spine. And this time, the thesis that it is the situational context that determines the experienced emotions, which are very expressively articulated by patients in medical interventions, was confirmed. In those situations, in which users experienced support, obtained necessary information in conversation, and had their doubts clarified - they felt "relative" peace, expressed confidence, slightly reduced anxiety related to the planned surgery - although fear, concern - am I going to wake up? - remained. Only in cases of emergency, life-saving procedures, patients expressed understanding for medical actions:

It is different when you have to act quickly, because human life is important. The doctor knows what to do and must think of the patient's life at all costs - this I understand - but otherwise it is necessary to talk, explain.

An interesting aspect of the analysis of the published statements was the fact that under the posts in which patients expressed concerns, anger, hostility and helplessness in relation to specific circumstances of the course of the visit or stay 
in hospital (specific situations), few users "picked up - continued" the pessimistic theme referring to their own experiences. The majority comforted, tried to point out the positive aspects, referring to their own or known experiences. They offered advice, help, recommended institutions and physicians who gained their trust.

I recommend the hospital [name of hospital], the doctors are friendly, they will explain, comfort, the nurses will help, talk, luckily there are still places like this.

It is interesting (and in a sense paradoxical), yet so natural, that extremely positive emotions were also invoked in the context of interactions with surgeons. The posts mainly highlighted the successful surgery, the healing process completed successfully, and patients expressed deep gratitude, joy, hope ("Doctor gave me back my life, I am extremely grateful"), happiness, trust. Joy, acceptance and trust were also expressed by patients (regardless of doctor's specialty) in the context of descriptions of visits, during which they felt that they were treated in a humane and dignified way, they had a sense of support, and the doctor was empathetic, understanding and patient.

When describing the process of experiencing an illness or a procedure, patients paid particular attention to interaction as a process of mutual influence. It was the interaction and communication that impacted on the way the patients experienced and perceived their illness (the therapeutic success was also important for them). Although the perception of health and illness is subjective, dependent on (generally) social factors, the recognition of the meaning that patients attribute to their condition and the emotions associated with it is particularly important in the process of diagnosis and treatment (cf. Kaźmierczak 2011: 135-136).

\section{Summary}

The analysis of the material unambiguously proves the contextual expression of emotions by users of the analyzed forums and portals. The causal context of a specific action triggered emotions that were being manifested via published descriptions and expressed opinions. Although the emergence of emotions initiates and is a motivator in the continuation of the sequence of behaviors leading to a specific goal - e.g., elimination of pain, improvement in health, this type of emotions among the analyzed threads appeared sporadically. The descriptions of specific situations and their consequences in the form of experienced emotions - in Ekman's terms - were significantly dominant.

The analysis of sources confirmed the thesis of the article, because the users of Internet portals more often published descriptions of situations (their contexts and the course of interaction) determining the experience of negative emotions, articulated in an expressive, evaluative way. Furthermore, it turned out that most emotions, such as fear, anger, frustration and hostility were evoked by situations 
in which the respondents described the lack of opportunity to obtain professional and competent medical assistance, respect for commonly accepted values and principles. Some concerned organizational issues.

A contemporary patient with their health issues must find themselves in a bureaucratic environment, conditioned by a complex network of legal, structural, organizational, social and economic dependencies. In the area of health-related activities, the entity is therefore not only a person waiting for a specific form of medical assistance, but also (and perhaps above all) a social entity, influenced by social, economic, political, cultural (+ religious) and psychological factors and principles (Mruk 2009: 49-52). From the analysis of users' statements emerges the profile of a patient who wishes to participate in the treatment process, gain knowledge about therapeutic options, establish a dialogue with the doctor (to be listened to and understood), build "contact" of an interactive nature. In descriptions of situations characterized by these qualities, patients expressed gratitude, trust, joy, and respect. However, they also often encountered barriers and struggled with the following organizational, personal, and quality-related problems: denial and limited accessibility to medical services (particularly specialized, diagnostic and outpatient), long waiting time for services; unethical behavior of medical personnel; objectification; inappropriate course of the patient-medical personnel relationship; refusal to share medical records; inadequate quality of services provided; improper organization of work and violation of patient rights.

Extremely negative emotions were expressed by patients describing the situations in which they did not receive consent to access their medical records, encountered difficulties in accessing medical services, pointed to the lack of respect for intimacy during the examination, did not receive information about the state of their health, the therapy provided, possible complications and effects of its abandonment. Although the process of communication between the doctor and the patient has been the subject of interdisciplinary analyses for many years and the issue of its importance is still raised, both in practical and ethical terms (ensuring the patient's participation in the diagnostic and therapeutic process, showing them respect and sense of dignity), the users of the analyzed portals and forums cited examples of situations indicating a lack of consideration for its importance.

By analyzing statements published on specific medical portals, it was also possible to categorize groups of healthcare providers. Generally, we can indicate that both extremely positive emotions (joy, trust, acceptance, happiness) and extremely negative emotions (anger, hostility, fear, anxiety) were expressed by respondents indicating the context of the situation related to the course of the interaction, the effect of the treatment process or the procedure performed. The most frequent participants in the interactions were the employees of: hospitals (public and non-public), basic medical care (public and non-public), outpatient specialist care, dentistry, rehabilitation, prevention programs, emergency care, long-term care. 
Analyzing the aforementioned data in a broader perspective, it can be said that, to some extent, they reflect an overall assessment of the Polish medical care system. From the data published in the 2019 report "Doświadczenia pacjentów w Polsce" based on a survey conducted among 2,000 Poles (Siemens Healthineers 2019) shows that " $18 \%$ of respondents have a positive opinion about healthcare in Poland. However, only $2 \%$ have a very good opinion about it. As many as $39 \%$ believe that Polish healthcare is either bad or very bad". Hospitals are rated the worst - most patients (about 40\%) rate the conditions and quality of care provided by them as bad. $20 \%$ of hospital patients indicated that medical staff did not care about the level of their pain. Patients also associated negative experiences with a lack of empathy and interest in their emotional state on the part of medical staff. In the in-depth interviews, the word "desensitization" (pol. znieczulica) was frequently used to refer to doctors and nurses. As many as $31 \%$ of patients and caregivers believe that the hospital medical staff did not take an interest in their emotional state, while 32\% indicated a lack of emotional support. Even worse is the organization of medical care. This sphere is evaluated negatively by as many as $53 \%$ of respondents (Siemens Healthineers 2019).

Therefore, it is not surprising that patients - mainly out of fear, helplessness, anger and frustration - not having received the expected support and help, look for it in the area about which they have a sense of security and are convinced that its scope will make it easier to reach people who can provide this help. The Internet is treated by them as a tool (cf. Castells 2003; Bolter 2002), thanks to which they are able to achieve their goals (cf. Skrzydlewski 1990), including expressive ones. Through the Internet, patients can both narrate their experiences and normatively reintegrate into society (cf. Gillett 2003). However, it is worrying that only $50 \%$ of Internet users remember the website addresses they browse, which may indicate the low importance placed on the source of health information and its quality (CBOS 2016). According to the Chief Sanitary Inspector, there is nothing wrong with using the web, the problem is what contents patients reach for and what conclusions they draw. "The Internet is now a repository of information, including in the area of health, which often comes from unreliable sources, from users who are not experts in the field" (Wojtasiński 2019).

\section{Bibliography}

Barometr WHC (2017), Raport na temat zmian $w$ dostępności do gwarantowanych świadczeń zdrowotnych $w$ Polsce, http://www.korektorzdrowia.pl/wp-content/uploads/barometrwhc xvii_2017_fin.pdf (accessed: 17.10.2020).

Batorski D., Marody M., Nowak A. (eds.) (2006), Społeczna przestrzeń internetu, Wydawnictwo Szkoły Wyższej Psychologii Społecznej Academica, Warszawa.

Bąk-Sosnowska M. (2006), Choroba w życiu czlowieka, [in:] A. Trzcieniecka-Green (ed.), Psychologia: podręcznik dla kierunków medycznych, Wydawnictwo Universitas, Kraków. 
Blumer H. (1969), Symbolic Interactionism. Perspective and Method, University of California Press, Berkeley-Los Angeles-London.

Boguszewski R. (red.) (2019), Rodzina - jej znaczenie i rozumienie, Komunikat z badań Centrum Badania Opinii Społecznej no. 22/2019, https://cbos.pl/SPISKOM.POL/2019/K_022_19.PDF (accessed: 27.08.2021).

Bolter J.D. (2002), Komputer: maszyna i narzędzie, [in:] M. Hopfinger (ed.), Nowe media w komunikacji spotecznej w XX wieku, Oficyna Naukowa, Warszawa.

Business Insider Polska (2019), Zdrowie w sieci, https://businessinsider.com.pl/technologie/nowetechnologie/medyczne-porady-w-internecie-czego-szukaja-polacy/snd19t3 (accessed: 20.07.2021).

Castells M. (2003), Galaktyka Internetu, transl. T. Hornowski, Dom Wydawniczy Rebis, Poznań.

Centrum Badania Opinii Społecznej (CBOS) (2016), Zdrowie i leczenie w Polsce, "Opinie i Diagnozy", no. 36, pp. 1-182.

DIGITAL (2020), "We Are Social”, https://wearesocial.com/digital-2020 (accessed: 23.08.2021).

Dolińska-Zygmunt G. (ed.) (2001), Podstawy psychologii zdrowia, Wydawnictwo Uniwersytetu Wrocławskiego, Wrocław.

Ekman P., Davidson R.J. (eds.) (1999), Natura emocji. Podstawowe zagadnienia, transl. B. Wojciszke, Gdańskie Wydawnictwo Psychologiczne, Gdańsk.

Gemius (2018), Wyniki badania Gemius/PBI za maj 2018, https://www.gemius.pl/wszystkieartykuly-aktualnosci/wyniki-badania-gemiuspbi-za-maj-2018.html (accessed: 18.04.2021).

Gillett J. (2003), Media activism and Internet use by people with HIV/AIDS, "Sociology of Health \&Illness", vol. 25(6), pp. 608-624, https://doi.org/10.1111/1467-9566.00361

Gregor B., Stawiszyński M. (2005), Wykorzystanie Internetu w badaniach panelowych rynku, [in:] A.R. Hochschild (2009), Zarzadzanie emocjami: komercjalizacja ludzkich uczuć, transl. J. Konieczny, Wydawnictwo Naukowe PWN, Warszawa.

Hochschild A.R. (2009), Zarządzanie emocjami: komercjalizacja ludzkich uczuć, transl. J. Konieczny, Wydawnictwo Naukowe PWN, Warszawa.

Jarosz M. (1978), Psychologia lekarska, Państwowy Zakład Wydawnictw Lekarskich, Warszawa.

Kacperczyk A. (2013), Praca nad emocjami jako element aktywności górskiej i wspinaczkowej, "Przegląd Socjologii Jakościowej”, vol. IX(2), pp. 70-103, https://doi.org/10.18778/17338077.16.4.02

Kaźmierczak A. (2011), Wpływ komunikacji z personelem medycznym na doświadczanie choroby przez pacjentów, https://depot.ceon.pl/bitstream/handle/123456789/1900/wplyw. pdf? sequence=1\&isAllowed=y (accessed: 12.04.2021).

Kemper T.D. (1987), How Many Emotions Are There? Wedding the Social and Autonomic Components, “American Journal of Sociology", vol. 93(3), pp. 263-289, https://doi. org/10.1086/228745

Kemper T.D. (2005), Modele spoleczne w wyjaśnianiu emocji, [in:] M. Lewis, J.M. Haviland-Jones (eds.), Psychologia emocji, transl. M. Kacmajor et al., Gdańskie Wydawnictwo Psychologiczne, Gdańsk.

Konecki K.T., Pawłowska B. (2013), W stronę socjologii emocji, "Przegląd Socjologii Jakościowej”, vol. IX(2), pp. 7-9.

Kowalski M., Gaweł A. (2006), Zdrowie - wartość - edukacja, Oficyna Wydawnicza „Impuls”, Kraków.

Krzywda I. (2017), Coraz dtuższe kolejki do płatnego leczenia. Lekarzy brakuje nam już wszędzie, http://www.dziennikpolski24.pl/aktualnosci/a/coraz-dluzsze-kolejki-do-platnego-leczenialekarzy-brakuje-nam-juz-wszedzie,12138426/ (accessed: 12.05.2021).

Lewis M., Haviland-Jones J.M. (eds.) (2005), Psychologia emocji, transl. M. Kacmajor et al., Gdańskie Wydawnictwo Psychologiczne, Gdańsk. 
Łaska-Formejster A. (2015), Pacjent $w$ sieci zależności. Spoleczny kontekst praw i autonomii pacjenta, Wydawnictwo Uniwersytetu Łódzkiego, Łódź, https://doi.org/10.18778/7969-815-8

Makara-Studzińska M. (2012), Komunikacja z pacjentem, Wydawnictwo Czelej, Lublin.

Mruk H. (2009), Marketing gabinetów lekarskich na rynku ustug zdrowotnych, Wolters Kluwer Polska, Warszawa.

Raport (2017), Lekarze w badaniach opinii społecznej 2017, Ośrodek Studiów, Analiz i Informacji Naczelnej Izby Lekarskiej, http://www.osai.nil.org.pl (accessed: 12.04.2021).

Siemens Healthineers (2019), Doświadczenia pacjenta w Polsce (raport badawczy), https:// static.healthcare.siemens.com/siemens_hwem-hwem_ssxa_websites-context-root/wcm/ idc/groups/public/@pl/documents/download/mda5/mze0/ edisp/siemens-healthineersdoswiadczenia-pacjenta-w-polsce-raport-06767911.pdf (accessed: 14.12.2020).

Skrzydlewski W. (1990), Technologia ksztatcenia, przetwarzanie informacji, komunikowanie. Zarys koncepcji środków dydaktycznych, Wydawnictwo Naukowe UAM, Poznań.

Staniszewska M. (2013), Internet jako narzędzie prowadzenia badań społecznych, „Acta Innovations", vol. 9, pp. 1-57.

Wojtasiński Z. (2019), Eksperci: w Internecie coraz więcej nieprawdziwych informacji o zdrowiu, Nauka w Polsce, http://naukawpolsce.pap.pl/aktualnosci/news\%2C33077\%2Ceksperci-winternecie-coraz-wiecej-nieprawdziwych-informacji-o-zdrowiu.html (accessed: 3.05.2019).

\title{
CZY STRACH POLSKIEGO PACJENTA MA WIELKIE OCZY? EMOCJE WYRAŻANE PRZEZ PACJENTÓW NA PORTALACH MEDYCZNYCH
}

\begin{abstract}
Abstrakt. W artykule podjęta została problematyka emocji doświadczanych przez pacjentów, użytkowników portali medycznych, którzy ,znaleźli się” w skomplikowanej strukturze systemu opieki zdrowotnej w Polsce, emocji wynikających z interakcji z pracownikami medycznymi oraz w procesie doświadczania przebiegu chorób. Analizie poddane zostały wypowiedzi opublikowane przez użytkowników portali/forów internetowych o tematyce medycznej. W skład próby badawczej weszło 15 portali medycznych, charakteryzujących się wysoką aktywnością zarejestrowanych użytkowników. Przedmiotem analizy były te wypowiedzi, w których pojawiał się opis sytuacji (lub ich kontekstu bądź działań uczestników interakcji) determinujących doświadczane emocje.

Słowa kluczowe: emocje polskich pacjentów, użytkownicy portali medycznych, zdrowie, działanie-sytuacja, system polskiej opieki medycznej.
\end{abstract}

